\title{
Spørgetid
}

\section{Hjælp til irakiske tolke?}

Spm. nr. $S 4233$

Spørgsmål til udenrigsministeren af Villy Søvndal (SF): "Hvilke aftaler, skriftlige eller mundtlige, er der indgået med partier i det danske Folketing om hjælp til de irakiske tolke, som har bistået de danske styrker i Irak?"

\section{Villy Søundal :}

Vi har alle sammen i Folketinget fået henvendelser fra danske officerer, der arbejder i Irak, og som er bekymrede over, hvad der sker med de tolke, der har hjulpet danskerne, når Danmark trækker sig tilbage til august. Derfor synes jeg, Folketinget har brug for at vide fra udenrigsministeren, hvad der egentlig er aftalt på de møder, der har været mellem udenrigsministeren og de forskellige partier, for der er mange forskellige tolkninger ude i offentligheden.

Baggrunden for mit spørgsmål er den moralske, at jeg kan ikke forestille mig, at man vil lade mennesker i stikken, der har hjulpet danske soldater. Det synes jeg var meget fornemt formuleret af en tidligere dansk udenrigsminister, Uffe Ellemann-Jensen, da han sagde: Man lader ikke den slags folk i stikken. Er udenrigsministeren enig i det, og foreligger der en aftale?

Udenrigsministeren (Per Stig Møller): Nu synes jeg såmænd ikke, hr. Villy Søvndal havde behøvet at citere min gode ven Uffe Ellemann-Jensen, for den danske regering har sagt præcis det samme igennem lang tid, og hvis hr. Villy Søvndal havde haft tid til at være i salen den 11. april, hvad det er helt i orden at han ikke havde tid til, så ville han have hørt det samme sagt af statsministeren på et spørgsmål fra hr. Rune Lund. Men allerede dagen før sagde statsministeren på sit pressemøde:

Det er vigtigt at slå fast, at tolke, der har hjulpet de danske soldater, undertiden i svære situationer, selvfølgelig ikke skal lades i stikken. Og så henviste han til, hvad jeg havde sagt: Udenrigsministeren har gentaget, at vi selvfølgelig ikke lader dem i stikken, og han har sagt, at sagerne vil blive behandlet efter de regler, der gælder, sagde statsministeren, der ikke kan udelukke, at de gældende regler vil betyde, at nogle af tolkene kommer til Danmark. Man kan hverken udelukke det ene eller det andet. 
Om mine samtaler med de forskellige partier kan jeg sige, at der ikke foreligger nogen hemmelig aftale. Man behøver ikke lave hemmelige aftaler om, at regeringen står ved sit løfte og sit tilsagn om ikke at lade nogen i stikken. Det er ikke aftalestof.

Jeg kan her over for hr. Villy Søvndal bekræfte, at jeg selvfølgelig over for partierne Dansk Folkeparti, Socialdemokratiet, Det Radikale Venstre, Venstre og Konservative under samtaler har sagt, at regeringen ikke vil lade tolkene i stikken, og at alle sager om asyl eventuelt, hvis de finder sted, vil blive behandlet inden for den eksisterende udlændingelovgivning. Det står regeringen ved, ligesom jeg også har sagt, at det vil ske på individuelt grundlag.

Så der har ikke været noget hemmeligt, og der er ikke noget bag gardinerne. Det hele har været sagt offentligt af denne regering igennem ganske lang tid. Så jeg synes, det skulle være ganske klart.

\section{Villy Søundal:}

Det er jeg ked af at jeg ikke kan sige at jeg synes det var, altså meget klart. Altså, en formulering, der hedder, at man ikke kan udelukke, som udenrigsministeren refererer statsministeren for, er jo som at sælge elastik i metermål. Det betyder, at man stort set kan gøre, hvad man vil. Men jeg forstår på udenrigsministeren, at der ikke foreligger nogen aftale, og det betyder, at når bl.a. hr.
Naser Khader siger, at der foreligger en aftale, så er det forkert efter det, vi i dag har fået oplyst af udenrigsministeren. Det, udenrigsministeren så rundede af med, er, at de skal behandles efter gældende asyllovgivning. Det betyder vel, at der ikke ligger nogen sikkerhed for tolkene, da vi også i den nuværende situation sender irakere tilbage til Irak.

Er det ikke det korte af det lange af udenrigsministerens svar, at der ikke ligger nogen form for sikkerhed? For hvordan kan man garantere menneskers sikkerhed i Irak med de forhold, der er gældende i dag?

\section{Udenrigsministeren:}

$\mathrm{Nu}$ er Folketingssalen jo ikke et sted, hvor man skal sagsbehandle individuelle sager. $\mathrm{Og}$ der vil være tale om individuelle sager. De skal så vurderes individuelt, og der skal drøftes med den enkelte tolk, hvad situationen er. Og så skal man finde en løsning for hver enkelt tolk.

Det er så der, statsministeren meget rigtigt har sagt, at man hverken kan udelukke det ene eller det andet. Der findes jo mange løsninger. Der findes lokale løsninger, der findes regionale løsninger, der findes også danske løsninger. Og det kan vi slet ikke stå og sagsbehandle her. Så det må da være noget, der skal vurderes konkret med de konkrete tolke og ikke af hr. Villy Søvndal i Folketingssalen. 


\section{Villy Søvndal:}

Jeg vil godt prøve igen, for jeg synes, ministeren er meget uklar. Og når ministeren er meget uklar, så er det, fordi han vælger at være meget uklar.

Når ministeren siger, at det er op til individuelle vurderinger, betyder det så, at hvis en tolk siger: Mit liv vil være truet, fordi jeg hjalp danske soldater - så vil man gå ind i en individuel vurdering og undersøge, om det mon også er rigtigt eller ej? Er det svaret? Jeg er med på, at vi ikke skal sagsbehandle, men betyder det, hvis en tolk siger:

Jeg er truet på mit liv - at man så vil sige, det er rigtigt, for når man har hjulpet danske soldater, der ikke længere er der, så er man truet på sit liv?

Så nævnte udenrigsministeren lokale løsninger. Er det muligt at uddybe lidt, hvad de kunne indeholde? Eller hvad regionale løsninger kunne gå ud på? Eller hvad danske løsninger kunne gå ud på?

\section{Udenrigsministeren:}

Når brigaden holder op med at være i Basra omkring 1. august, skal aftackling finde sted. Der er selvfølgelig en masse opgaver, der skal sørges for, således man rykker ordentligt ud. Der er også de civile projekter, som skal overdrages til irakerne selv på en måde, som gør, at de kan videreføres. Så der er en masse, om jeg så må sige, afleveringsforretninger.
En af de ting, der også skal tages hånd om, når man rykker planmæssigt ud, er selvfølgelig bekymringen fra tolkenes side. Derfor kan det selvfølgelig kun foregå individuelt, for bekymringerne kan være forskellige, ønskerne kan være forskellige. Nogle kan have ønske om det ene sted i Irak eller et andet sted i Irak, nogle kan have ønske om noget andet et andet sted i regionen, sådan som det fx er sket for Englands vedkommende. Og nogle kan føle, at der kun er én mulighed, og det er i Danmark.

Sådan vil det være forskelligt fra familie til familie, fra tolk til tolk, og det er derfor, brigaden skal have kontakt med dem. Det er en del af den samlede afvikling 1 . august også at have afviklet og sørget for, at ingen af dem, vi taler om her, lades i stikken.

\section{Villy Søundal:}

$\mathrm{Nu}$ synes jeg måske, vi begynder at komme lidt tættere på. Jeg forstod, at de tolke, der udtrykker, at deres liv er i fare, vil man med udenrigsministerens ord tillade at komme til Danmark, hvis det er deres eneste mulighed for at føle tryghed.

Er det rigtigt, at hvis en tolk siger: Mit liv er så truet, at kun Danmark kan yde mig den fornødne sikkerhed - så er regeringen villig til at tage konsekvensen af det? I så fald synes jeg bestemt, at det har været en nyttig eftermiddag, og jeg vil også sige trøstende til udenrigsmini- 
steren, at han ikke behøver at være bange for at sige det højt, for Dansk Folkeparti er ikke til stede i salen lige nu. Så der er ingen, der kommer efter udenrigsministeren. Han kan i det her tilfælde fuldstændig frit give udtryk for sin holdning.

Men må jeg tolke det sådan, at udenrigsministerens svar er, at de tolke, der mener, at deres sikkerhed kun kan tilgodeses i Danmark, efter i dag har udenrigsministerens løfte om, at de kan komme til Danmark?
Udenrigsministeren (Per Stig Møller): Der skal ikke gives løfter her i Folketingssalen. Det afgørende er, at der vil ske en individuel vurdering, som vil blive drøftet med hensyn til den enkelte tolk, og jeg skal ikke her i Folketingssalen forudskikke, hvad denne samtale ender med.

Jeg kan kun sige, som statsministeren sagde den 10. november: Man kan hverken udelukke det ene eller det andet.

Folketinget, 25. april 2007 